\title{
Kinetic Modeling of Vitamin C (Ascorbic Acid) Degradation in Blanched Commonly Consumed Salad Vegetables Using Computer Simulation Analysis
}

\author{
${ }^{1}$ Awagu, E.F., ${ }^{2}$ EKANEM, E.O.,${ }^{2}$ Kolo, A.M..${ }^{3}$ Adamu, M.M. \\ ${ }^{I}$ Nigerian Stored Products Research Institute, P.M.B.3032 Hadejia Road Kano, Nigeria \\ ${ }^{2}$ Department of Chemistry, Abubakar Tafawa Belewa University, P.M.B. 0248 Bauchi, Nigeria. \\ ${ }^{3}$ Department of Mathematics, Abubakar Tafawa Belewa University, P.M.B. 0248 Bauchi, Nigeria.
}

\begin{abstract}
Vitamin C (ascorbic acid) is one of the most important and popular vitamins, and is contained in most fruits and vegetables; the problem with vitamin $C$ is its easy degradation during processing. In this study, the degradation kinetics of vitamin $C$ was determined in Lettuce and Cabbage, and the processing treatment considered was blanching at $70^{\circ} \mathrm{C}$ of water differently for 5, 10, 15, 20,25,30,35 and 40 minutes. Samples were dried in mild temperature $\left(15-20^{\circ} \mathrm{C}\right)$ and ground to find dust and High Pressure liquid chromatographic (HPLC) was used for determination of the AA of vegetable salad samples which consisted of an isocratic elution procedure with $U V$-Visible detection at $245 \mathrm{~nm}$. The rate constants were calculated for both vegetable salad samples under the same processing method using the integrated law method; half-life was also calculated. Degradation of ascorbic acid in Lettuce and Cabbage under the same pretreatment procedure followed the firstorder kinetic model, as the coefficient of determination $\left(R^{2}\right.$-value) were 0.8981 and 0.9785 respectively. The rate constant of ascorbic acid degradation for Lettuce and Cabbage under the same blanching conditions were 0.099 min-1 and 0.088 min-1 respectively. The half-life of Lettuce and Cabbage were 420.0892 and 472.6004 seconds respectively. The most appropriate vegetable salad under the blanching pretreatment procedure is the cabbage because its rate constant depicted from the model equations was lower, and the half life longer, hence, slower rate of degradation. The first order forecast $(\operatorname{Ln}(C))$, was 0.657964 for Lettuce and 1.330017 for Cabbage, which further authenticate that blanched Lettuce degradation was higher than Cabbage under the same pretreatment conditions.
\end{abstract}

Keywords: HPLC, Lettuce, Cabbage, Blanching, Ascorbic Acid, Rate Constant

\section{Introduction}

Vegetables are low in fat and energy with high carbohydrate and fibre contents, providing significant levels of some micronutrients [1]. Cultivated Lettuce (Lactuca sativa L.) is a widely grown and popularly consumed leafy vegetable because it contains vitamin C, polyphenols, and a dietary fiber, which contribute to weight loss (due to its low caloric content), lower the risk of cardiovascular diseases (via reducing low-density lipoprotein (LDL) cholesterol and blood pressure), and reduce the risk of diabetes (by improving glucose metabolism) and colon cancer (due to protective role of dietary fiber) [2]. The major traditional use of lettuce is as a sleep inducer. Research into the extracts of Lettuce resulted in the isolation of a depressant chemical.This chemical, when admistered in experimental animals, showed significant sedative effects [3]. On the other side Cabbage or headed cabbage (comprising several cultivars of Brassica oleracea) is a leafy green or purple biennial plant, grown as an annual vegetable crop for its dense-leaved heads. It is an excellent source of vitamin C and vitamin K, containing more than $20 \%$ of the Daily Value (DV) for each of these nutrients per serving [4]. The Ancient Greeks recommended consuming the vegetable as a laxative and used cabbage juice as an antidote for mushroom poisoning [5, 6]. For eye salves, and for liniments used to help bruises heal [7].

Vitamin C (ascorbic acid, AA) is an important component of our nutrition. It prevents scurvy and protects the body from oxidative stress which might lead to cancer, inflammation, cardiovascular diseases, asthma and arteriosclerosis [8]. Plants can make it themselves as can some animals, but humans do not have the right enzyme (gulonolactone oxidase) to synthesize this vitamin, hence, ascorbic acid has to be supplemented mainly through fruits and vegetables. Ascorbic acid is known to be a vitamin sensitive to a number of factors, including $\mathrm{pH}$, moisture content, light, oxygen and temperature [9]. Its degradation proceeds in both aerobic and anaerobic pathways and depends upon many factor, such as oxygen, light, heat, storage temperature and storage time [10, 11]. Oxidation of ascorbic acid occurs mainly during the processing of juices, whereas, anaerobic degradation mainly appears during storage [12]. The nutrient quality of food during processing has become increasingly important. The degradation of some nutrients such as vitamin $\mathrm{C}$ during processing might be a critical factor for the shelf life of some products such as juice concentrate, since vitamin $\mathrm{C}$ content of fruits undergoes destruction during storage [13]. Pretreatment are common in most of the drying process order to improve product quality, 
storage stability and processing efficiency. In recent years, an improvement in quality retention of the dried products by altering processing strategy and pretreatment has gained much attention.

Blanching is a process of preheating the product by immersion in water or steam. The main purpose of blanching is to inactivate the naturally occurring enzymes present in foods, since enzymes are responsible for off-flavour development, discoloration or browning, deterioration of nutritional quality and textural changes in food materials. Other advantages are that it removes air-bubbles from vegetable surfaces and from intercellular spaces, reducing the initial microbial load, cleans raw food material initially, facilitating preliminary operations such as peeling, dicing, improving color, texture and flavor under optimum conditions [14,15,16]. Blanching may have disadvantages for example, it may change the texture, color and flavor because of the heating process $[17,18]$. It increases the loss of soluble solids, such as vitamins, especially in the case of water blanching [19, 20].It changes the chemical and physical states of the nutrients and vitamins [21, 14, 22]. It has adverse environmental impacts, such as large water and energy usage and problem of effluent disposal. Time and temperature of blanching are the important factor for achieving optimum quality of the dried products [10]. The normal blanching temperature varies from $80^{\circ} \mathrm{C}$ to $100^{\circ} \mathrm{C}$. Recently, low temperature and long-time blanching has been proposed for better texture and retention of some nutritional components [23, 24]. The temperature used in between $50^{\circ} \mathrm{C}$ and $70^{\circ} \mathrm{C}$, blanching times correlated with the flavor and sensory attributes of dried fruits and vegetables [18]. Limiting blanching time, rapid cooling and alternative blanching methods and combinations may result in dried products with better flavor. Processing methods that include steam and microware blanching and non thermal enzyme inactivation such as high pressure and ohmic heating may hold out potential for future blanching processes with less detrimental effects or flavor while maintaining optimum texture. Therefore, a deep knowledge of vitamin $\mathrm{C}$ degradation such as the kinetic order, and rate constants are the basic requirements to define the shell life of fruit juice and related products [25]. Numerous analytical techniques are available for the determination of the vitamin $\mathrm{C}$ content in various fruits and vegetables, amongst them are HPLC, Iodometric titration, chromatographic methods, enzymatic methods, and electrochemical methods [26, 27, 28, 29]. Kinetics can be defined as the rate at which reaction occurs. Changes occur at certain reaction rates.

Kinetic modeling enables to describe these changes and their rates quantitatively. Kinetic modeling also enables us understand the basic reaction mechanisms vital for quality modeling and control. The degradation kinetics of ascorbic acid in model systems conforms to first order kinetics, however, in food systems the kinetics is somehow complex [30]. The complexity of the degradation mechanisms hinders the development of mechanistic models, and pseudo-kinetic model such as zero order, first-order or second-order kinetics are often applied in order to obtain a good fit to the experimental data. The model that gives the highest coefficient of determination value $\left(\mathrm{R}^{2}\right)$ value) is regarded as the best fit for the analysis [31].Time series is a chronological sequence of observations on a particular variable. Usually the observations are taken at regular intervals (minutes, days, months, years), but the sampling could be irregular.. A time series analysis consists of two steps: (1) building a model that represents a time series, and (2) using the model to predict (forecast) future values. The objectives of this study were (i) to determine the rate of degradation of vitamin $\mathrm{C}$ in Lettuce and Cabbage under the same pretreatment conditions of blanching at $70^{\circ} \mathrm{C}$ of water, so as to recommend the best; (ii) to develop kinetic models for predicting vitamin $\mathrm{C}$ degradation in Lettuce and Cabbage under the studied conditions. (iii) to predict the future values(forecast)

\subsection{Reagents and chemicals}

\section{Methods And Materials}

L-ascorbic acid (AA), metaphosphoric acid (MPA),orthophosphoric acid, and acetonitrile (HPLCGrade) were all purchased from Merck (Darmastdt, Germany).For chromatographic analysis, de-ionized water of $18 \mathrm{M} \Omega \mathrm{cm}^{-1}$ resistivity purified with a milli-Q system(Millipore, Bedford, USA) was used. Ascorbic acid stock standard solution was prepared in water and stored in a glass-stopper bottle at $4^{0} \mathrm{C}$ in the dark [32].

\subsection{Sample preparation}

Lettuce and Cabbage were sourced matured and fresh from fruits and vegetable market located in Yankaba, Nasarawa local Government of Kano state Nigeria which lies between Longitude $7^{0} 54^{\prime}$ and $9^{0} 06^{\prime}$ East and Latitude $11^{\circ} 37^{\prime}$ and $12^{\circ} 21^{\prime}$ north. The fresh and matured vegetable salad $(900 \mathrm{~g})$ each were immediately washed with clean water to remove dirt and soil, and then drained with muslin cloth to remove unwanted water. Stems were removed by cutting with a sharp and washed knife to avoid contamination. The leaves $\left(100 \mathrm{~g}\right.$ ) each was then blanched in two (2Litres) of water differently at $70^{\circ} \mathrm{C}$ for $5,10,15,20,25,30,35$ and 40 minutes. The blanched samples were cooled immediately to stop further cooking under running tap water for 2 minutes, drained differently using muslin cloth for 5 minutes and the initial samples were blended in a Kenwood blender (Philips, HR 1702, Borehamwood, England, UK) and filtered with cheese-cloth. The liquid extracts were used to assess the initial of ascorbic acid degradation during blanching. The remaining lots were spread evenly on trays and dried under room mild temperature and relative humidity using hygrometer. 
Untreated sample served as the control. After drying they were blended, filtered and liquid extract used to determine the final rate of degradation of ascorbic acid. Experiments were carried out in 3 replications and the average of measurement was reported.

2.3 Instrumentation

The HPLC system consists of Waters liquid chromatograph (Milford, MA, USA) equipped with a 600E multisolvent delivery system, an in-line degasser, a manual injection with $20 \mu \mathrm{L}$ loop (Rheodyne 7125), and Waters $2487 K$ dual absorbance detector. Empowers software was used for controlling the analytical system and data processing.

\subsubsection{Extraction of ascorbic acid}

\subsubsection{Mild-temperature-drying procedure}

This procedure is a modification of the method done by [33]. About $100 \mathrm{~g}$ of salad vegetable samples in each maturity stage were separately weighed and dried under mild temperature $\left(15-20^{\circ} \mathrm{C}\right)$ and ground to find powder dust before extraction. Then obtained powder were weighed $(1.0 \mathrm{~g}$ for each sample and subsequently extracted with $25 \mathrm{~mL}$ of extractant solution, containing 5\% MPA, at $10^{\circ} \mathrm{C}$ and in the dark. Extraction process was performed using a shaker for $4 \mathrm{~h}$. All extractions were carried out in triplicate and obtained solutions were then filtered and stored at $4^{0} \mathrm{C}$ before analysis. The injection of the extracts into HPLC system was performed twice

\subsubsection{HPLC analysis}

The liquid chromatographic method used for the determination of AA consisted of an isocratic elution procedure with UV-Visible detection at $245 \mathrm{~nm}$. Separations were carried out on a $5 \mu \mathrm{m}$ RP C18 column of $250 \mathrm{~mm} \times 4.6 \mathrm{~mm}$ (Spherical, Optimals ODS-H, Capital HPLC, UK) fitted with a $5 \mu \mathrm{m}$ RP C18 guard column of $20 \mathrm{~mm} \times 4.6 \mathrm{~mm}$ (Spherical, Optimals ODS-H, Capital HPLC, UK). The mobile phase employed was a mixture of $0.5 \% \mathrm{NaH}_{2} \mathrm{PO}_{4}\left(\mathrm{pH} 2.25\right.$ with $\mathrm{H}_{3} \mathrm{PO}_{4}$ )-acetonitrile (93:7). Flow rate of the mobile phase was $1.2 \mathrm{~mL} \mathrm{~min}^{-1}$ and an injection volume of $20 \mu \mathrm{L}$ was used in quantitative analysis. The temperature of analytical column was kept constant at $25^{\circ} \mathrm{C}$. The calibration curve and quantitative evaluations were accomplished at $245 \mathrm{~nm}$. Standard solutions and extracts were filtered through a prefilter and then a $0.45 \mu \mathrm{m}$ millipore membrane before their injection. To prevent the loss of AA, standard solutions and extracted samples were protected from light using amber flasks. Quantitation was performed by comparing the chromatographic peak area with that of the external standard. The calibration curve was plotted in the concentration range of $0.5-200 \mathrm{mg} \mathrm{L}^{-1}$ and based on a 10-point calibration.

\subsection{Kinetic modeling}

The degradation of vitamin $\mathrm{C}$ was modeled using the integrated rate law. Different models were developed using the integral method of analysis. The integral law equation stated below;

$\mathrm{dC} / \mathrm{dt}=-\mathrm{K}[\mathrm{C}]^{\mathrm{n}}$

was used to develop three models based on concentration (for order of reaction $n=0,1$ and 2) and their associated half lives $\left(\mathrm{t}_{1 / 2}\right)$.

Zero order model $(\mathrm{n}=0)$ :

$\mathrm{C}=\mathrm{C}_{0}-\mathrm{Kt}$

$\left(\mathrm{t}_{1 / 2}\right)=\mathrm{C}_{0} / 2 \mathrm{~K}$

First order model $(\mathrm{n}=1)$ :

$\ln (C)=\ln \left(C_{0}\right)-k t$

$\left(\mathbf{t}_{1 / 2}\right)=\ln (2) / \mathbf{k}$

Second order model $(\mathrm{n}=2)$ :

$$
1 \sqsubset \mathrm{C}=1 \sqsubset \mathrm{C}_{0}+\mathrm{Kt}
$$

$\mathbf{t}_{1 / 2}=\mathbf{1} / \mathbf{k} \mathrm{C}_{\mathbf{0}}$

Where, $\mathrm{K}=$ rate constant

$\mathrm{C}_{0}=$ initial concentration of vitamin $\mathrm{C}$ in sample

$\mathrm{C}=$ concentration of vitamin $\mathrm{C}$ in sample at time $\mathrm{t}$

$\mathrm{t}_{1 / 2}=$ half-life of vitamin $\mathrm{C}$ in sample

Concentration or a function of concentration was plotted against time for each model and regression analysis was used to determine the 'Goodness of fit' employing Minitab 17.3.1, 2016 [34]. Goodness of fit is 
characterized by coefficient of determination $\left(\mathrm{R}^{2}\right), \mathrm{R}^{2}$ adjusted is the percentage of response variable variation that is explained by its relationship with one or more predictor variables, adjusted for the number of predictors in the model. Regression p- Value when small (typically $\leq 0.05$ ) indicates strong evidence against the null hypothesis. The kinetic model could be developed based on the predicted initial contents, measured contents and processing time. This was achieved using the statistical program [35].A multiple comparison of the treatment means was performed by Duncan's New Multiple Range test. The model with maximum $\mathrm{R}^{2}$ and minimum $\mathrm{p}$ Value is adjudged the best $[36,37]$.

\section{Results And Discussion}

The variations in vitamin $\mathrm{C}$ concentration of vegetables samples during processing is presented in tables 1 and 2.Table 3 summarize the results of kinetic model regression analysis, while Table 4 compares vitamin $\mathrm{C}$ first order kinetics degradation parameters for the samples under the same processing method with Zero and Second order kinetics. As can be observed in Table 1 and 2 the concentration of vitamin $\mathrm{C}$ decreased steadily with time during processing in all the samples. This confirms the fact that vitamin $\mathrm{C}$ in salad vegetables degrade during processing [31]. This is in an agreement with the report of earlier workers on blanching of fruits and vegetables that ascorbic acid is water soluble that makes it prone for leaching from cells [38]. It is thermally labile, pH-, metal- ion-, and light-sensitive, and can be degraded by ascorbic acid oxidase [38, 39] and in accordance with the degradation kinetics of ascorbic acid in model systems as put forth by Liao [30]. Therefore, ascorbic acid is usually selected as the most frequently measured nutrient to evaluate the nutrients loss during blanching process. The preservation of

ascorbic acid after blanching is a good indicator for the preservation of other nutrients [40, 41].The vitamin $\mathrm{C}$ concentration of the salad vegetable samples with respect to time decreased during processing, but in different degrees, depending on nature of salad vegetables. This is in agreement with the report of earlier workers on citrus and strawberry fruit juices [13, 25], and in accordance with the degradation kinetics of ascorbic acid in model systems as put forth by Liao and Seib [30]. Besides, in a recent investigation by NEWHEALTHADVISOR, 2017 the ascorbic acid content in a given mass of Cabbage was found to be greater than that in an equal mass of Lettuce [34]. This is confirmed by this study; as the concentration of vitamin $\mathrm{C}$ in Cabbage is greater than that in Lettuce for the same mass of sample after blanching. A visual inspection of the kinetic plots of models (2a),(3a) and (4a) presented in Figures 1-3 for Lettuce, and in Figures 4-6 for Cabbage, shows that the first order model fitted the kinetic data best in all vegetable samples.

Table 1. Vitamin C concentration in Lettuce during processing

\begin{tabular}{|l|l|l|l|}
\hline Processing Treatment & Sample Code & Minutes & Vitamin C(mg/100g) \\
\hline Blanching & LE1 & 5 & 29.36 \\
\hline & LE22 & 10 & 61.93 \\
\hline & LE43 & 15 & 30.36 \\
\hline & Le51 & 20 & 15.19 \\
\hline & Le52 & 25 & 10.06 \\
\hline & Le53 & 30 & 7.1 \\
\hline & Le54 & 35 & 2.98 \\
\hline & Le55 & 40 & 1.27 \\
\hline
\end{tabular}

Table 2. Vitamin $\mathrm{C}$ concentration in Cabbage during processing

\begin{tabular}{|l|l|l|l|}
\hline Processing treatment & Code & Time(minutes) & Vitamin C(mg/100g) \\
\hline Blanchining & CA8 & 5 & 68.72 \\
\hline & CA29 & 10 & 59.57 \\
\hline & CA50 & 15 & 36.49 \\
\hline & Ca1 & 20 & 25.48 \\
\hline & Ca11 & 25 & 15.41 \\
\hline & Ca22 & 30 & 6.96 \\
\hline & Ca33 & 35 & 5.32 \\
\hline & Ca37 & 40 & 4.3 \\
\hline
\end{tabular}

Table 3. Results of kinetic model statistical analysis for Lettuce and cabbage

\begin{tabular}{|l|l|l|l|l|l|}
\hline $\begin{array}{l}\text { Processing } \\
\text { method }\end{array}$ & $\begin{array}{l}\text { Vegetables } \\
\text { Blanched }\end{array}$ & $\begin{array}{l}\text { Kinetic } \\
\text { Order(n) }\end{array}$ & $\mathrm{R}^{2}$ & $\begin{array}{l}\text { Adjusted } \\
\mathrm{R}^{2}\end{array}$ & P-Value \\
\hline $\begin{array}{l}\text { Blanched } \\
\text { at70 } \mathrm{C} \mathrm{H}_{2} \mathrm{O}\end{array}$ & Lettuce & 0 & 0.662439 & 0.606179 & 0.013947 \\
\hline & Cabbage & 0 & 0.909433 & 0.894338 & 0.00024 \\
\hline & Lettuce & 1 & 0.898063 & 0.881073 & 0.000345 \\
\hline & Cabbage & 1 & 0.97848 & 0.974893 & 0.00000314 \\
\hline & Lettuce & 2 & 0.643376 & 0.583938 & 0.016613 \\
\hline & Cabbage & 2 & 0.887244 & 0.868451 & 0.000468 \\
\hline
\end{tabular}


Table 4. Comparison of first order kinetic parameters, proposed model and Paired Samples Statistics

\begin{tabular}{|l|l|l|l|l|l|l|l|}
\hline $\begin{array}{l}\text { Processing } \\
\text { Method }\end{array}$ & $\begin{array}{l}\text { Vegetables } \\
\text { Blanched }\end{array}$ & $\begin{array}{l}\text { Kinetic } \\
\text { Order(n) }\end{array}$ & Mean & $\begin{array}{l}\text { Rate Constant } \\
\text { K (Min) })\end{array}$ & $\begin{array}{l}\text { Half Life } \\
\mathrm{t}_{1 / 2}\end{array}$ & $\begin{array}{l}\text { Forecast } \\
\ln (\mathrm{C})\end{array}$ & $\begin{array}{l}\text { Proposed } \\
\text { Model }\end{array}$ \\
\hline & Lettuce & 1 & 2.4049 & 0.099 & $420.0892 \mathrm{sec}$ & 0.657964 & $\ln (\mathrm{C})=\ln \left(\mathrm{C}_{0}\right)-0.099 \mathrm{t}$ \\
\hline & Cabbage & 1 & 2.8697 & 0.088 & $472.6004 \mathrm{sec}$ & 1.330017 & $\ln (\mathrm{C})=\ln \left(\mathrm{C}_{0}\right)-0.088 \mathrm{t}$ \\
\hline
\end{tabular}

This is confirmed by the goodness of fit data in Table 3.The first order kinetics exhibited $\mathrm{R}^{2}$ values; 0.8981, P-value; 0.000345 for Lettuce and $\mathrm{R}^{2}$ values; 0.97848 , P-value; 0.00000314 for Cabbage under the same blanching conditions. The $\mathrm{R}^{2}$ value of Cabbage was highest with $\mathrm{P}$ - value lowest as compared with Lettuce, $\mathrm{R}^{2}$ lowest with $\mathrm{P}$-value highest.Signifying that as the $\mathrm{R}^{2}$ increases, the $\mathrm{P}$-value decreases. Thus, the vitamin $\mathrm{C}$ degradation kinetics in Cabbage and Lettuce can be best described by a first order kinetics. This implies that the rate of degradation at any time is dependent on the initial concentration of vitamin $\mathrm{C}$ in the Salad vegetables. Furthermore, the rate constant of Salad vegetable (Cabbage) was lower than that of Lettuce.

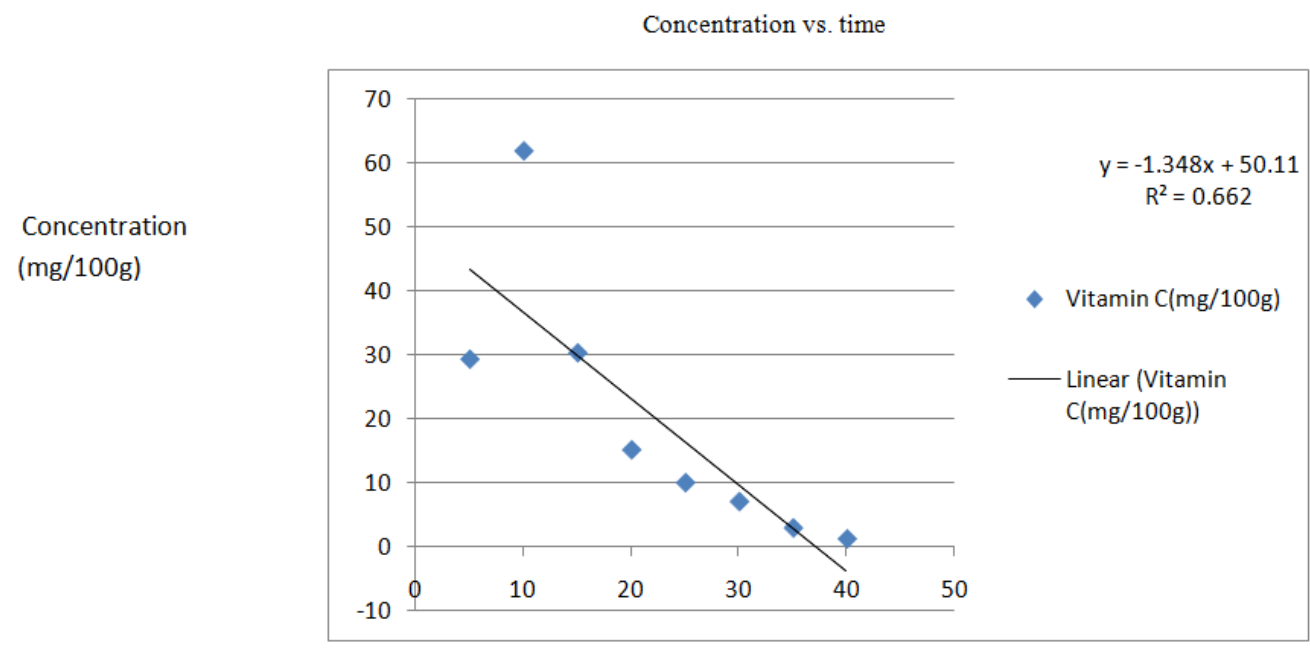

Time (minutes)

Fig. 1. A plot of zero order kinetics for Lettuce (concentration vs. time)

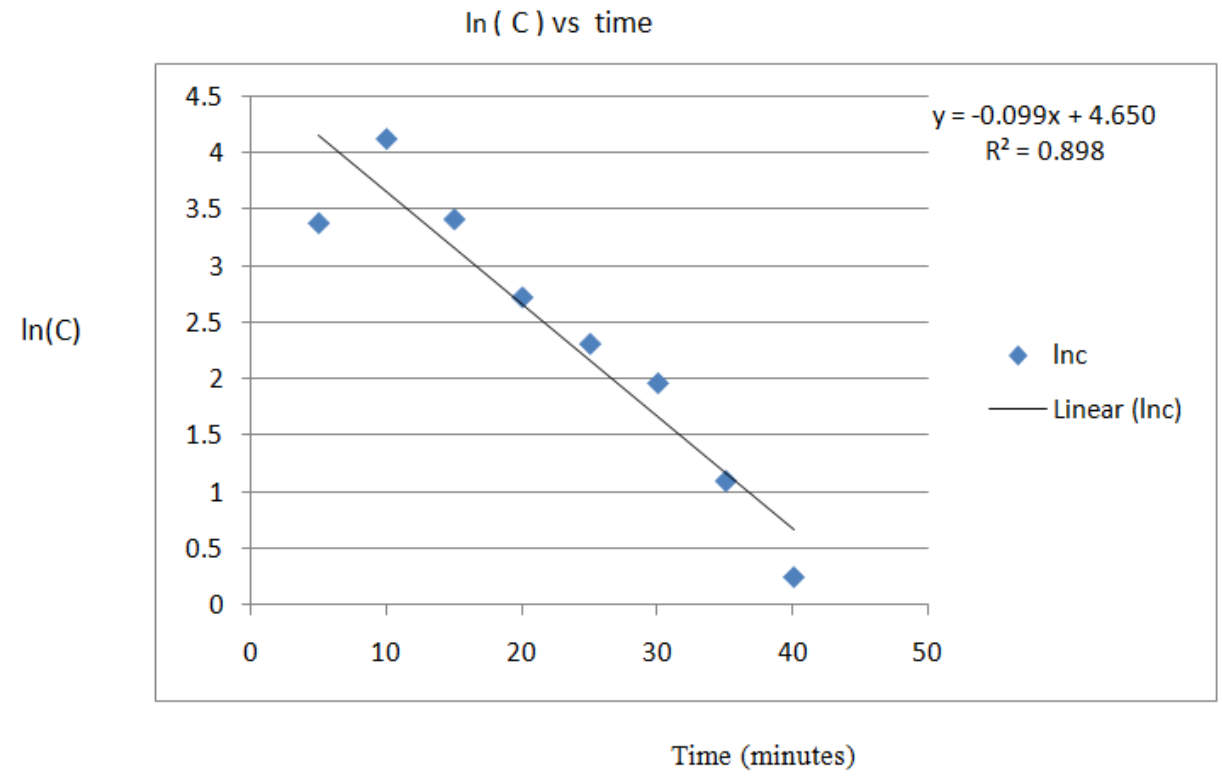

Fig. 2. A plot of first order kinetics for Lettuce $\ln (C)$ vs. time) $C=$ concentration 


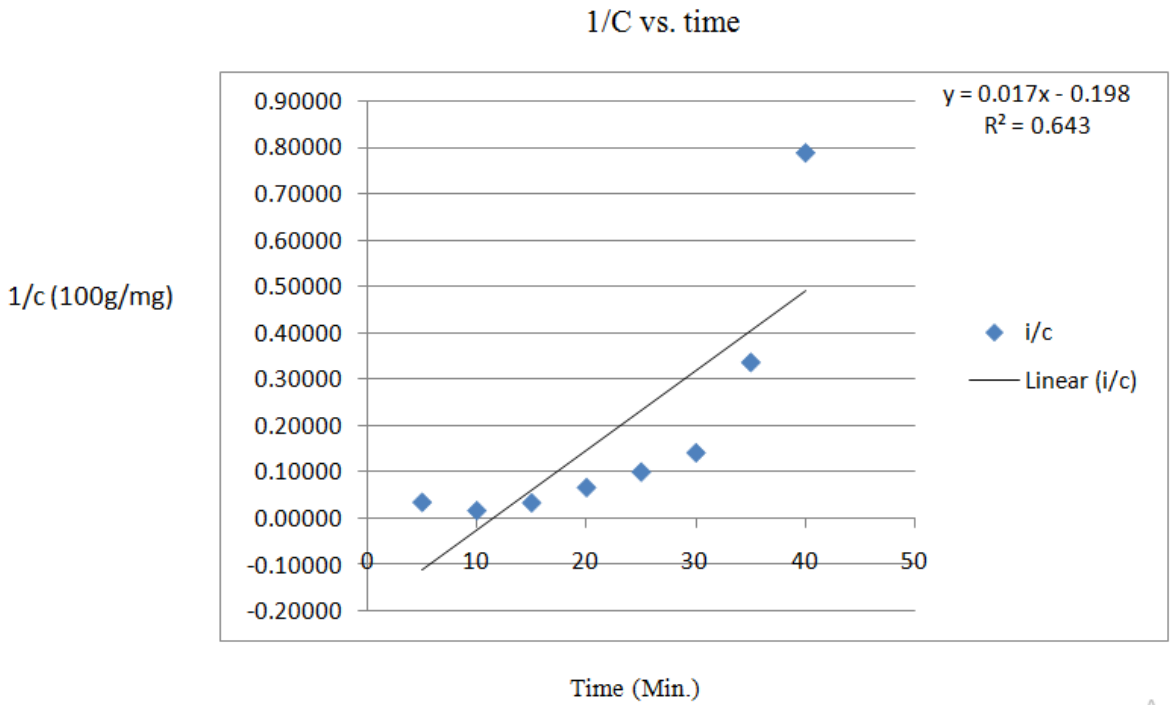

Fig. 3. A plot of second order kinetics for Lettuce (1/C vs. time)

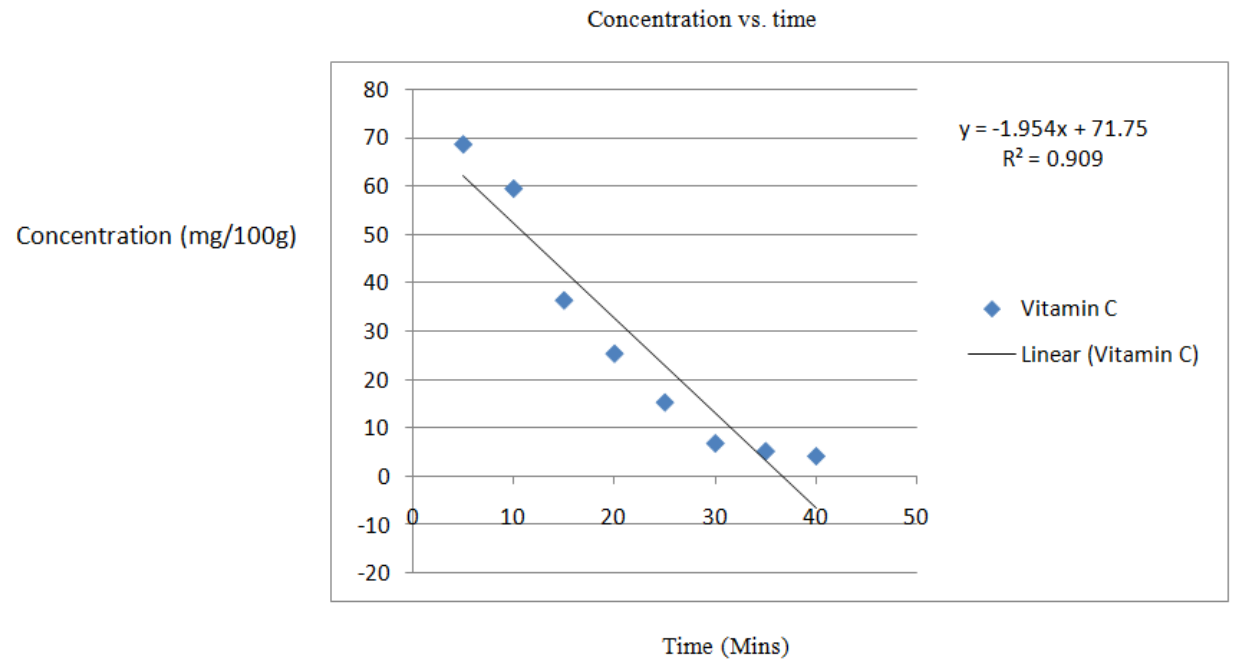

Figure 4. A plot of zero order kinetics for Cabbage (concentration vs. time)

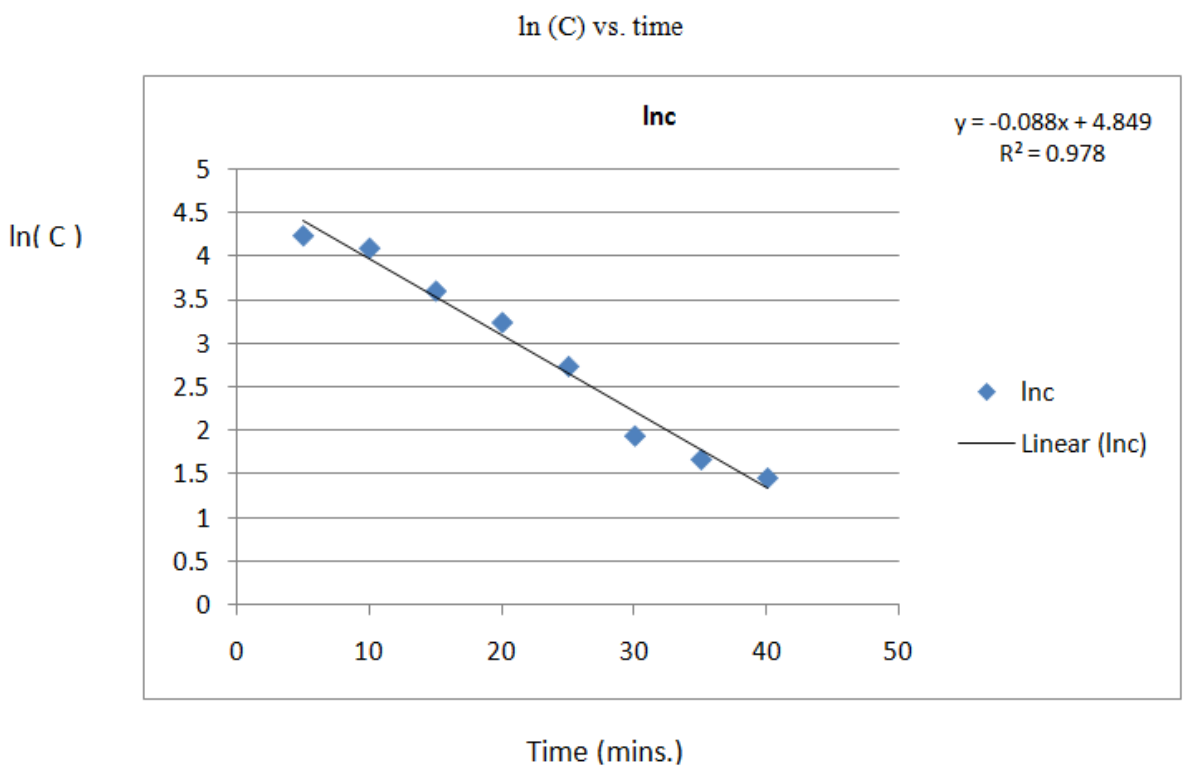

Fig. 5. A plot of first order kinetics for Cabbage (ln C vs. time) 


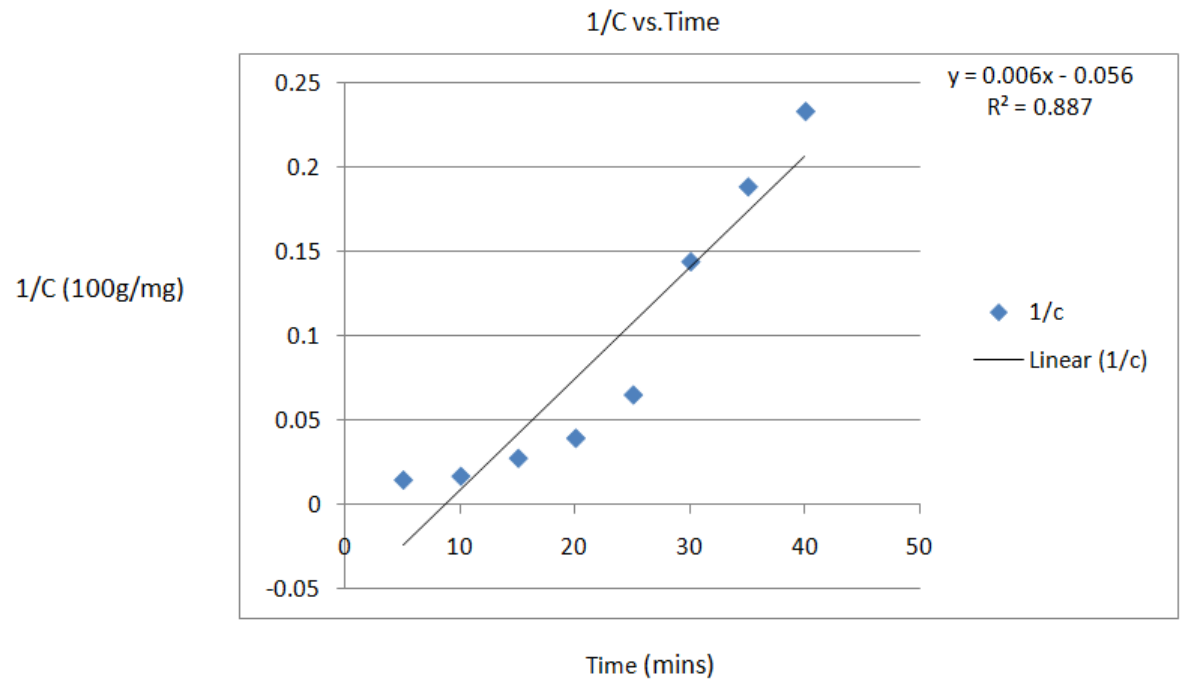

Fig. 6. A plot of second order kinetics for Cabbage (1/C vs. time)

The lettuce and cabbage salad vegetable samples exhibited rate constants of $0.099 \mathrm{~min}-1$ and $0.088 \mathrm{~min}$ 1 respectively, of which cabbage was the lowest. Since the magnitude of the rate constant is a reflection of the rate of reaction, the inference is that degradation of vitamin $C$ occurred faster in Lettuce sample than Cabbage [31]. This trend manifested in the half life of the samples which gives further credence to this fact. The time at which the concentration of vitamin $\mathrm{C}$ in the Lettuce sample reduces to half of its original amount (half life) was shorter than in Cabbage sample. This implies that the Cabbage sample will be expected to have longer shelf life than the Lettuce. Cabbage salad vegetable sample recorded the longest half life of 472.6004 seconds while Lettuce had the shortest half life of 420.0892seconds.The mean value quantified individual models, for first order, the mean value was 2.4049 for Lettuce and 2.8697 for Cabbage, which implies that the higher the mean value for specified model the lesser the rate of degradation.ln(c) forecast; 1.3300 for Cabbage and $\ln (\mathrm{C})$; 0.6580 for Lettuce, which further authenticate that blanched Lettuce degradation was at higher rate than Cabbage under the same pretreatment conditions.

\section{Conclusion}

The rate of vitamin $\mathrm{C}$ degradation in the Lettuce and Cabbage samples under the same processing method investigated in this study followed a first order reaction kinetics. This indicates that the rate of degradation is dependent on the concentration of the vitamin $\mathrm{C}$ present in both vegetables. In addition, pretreatment of salad vegetable (Lettuce) resulted in faster rate of degradation of vitamin C than vegetable Salad (Cabbage). This impresses the fact that the blanching of Cabbage at $70^{\circ} \mathrm{C}$ of water is more preferable in terms of vitamin $\mathrm{C}$ retention than Lettuce, hence, is recommended for food supplement Industries to deploy this research findings for further processing into semi and finished products after dehydration because degradation of vitamin $\mathrm{C}$ during processing might be a critical factor for the shelf life of some products such nutrient concentrates, since vitamin $\mathrm{C}$ content of fruits undergoes destruction during processing and storage.

\section{Acknowledgements}

The authors would like to acknowledge the assistance rendered by the Industrial Training students attached to Nigerian Stored Product Research Institute (Victor Bawa, Tabita, Stephen and Mohamade) for periodic monitoring of samples in Laborator

\section{References}

[1]. Charles, C.A., Diana, K.A.,and Chiemela E.C.2011, Kinetics of ascorbic acid loss during hot water blanching of fluted pumpkin (Telfairia occidentalis) leaves: J Food Sci Technol.Res., 48(4), 454-459.

[2]. Kim,M.J., Youyoun M., Janet C. and Tou, N. L. Waterland 2016.Nutritional Value, Bioactive Compounds and Health 3.Organic Tracts(2017).Organic Information Services Pvt ltd,603,55 Corporate Avenue.Saki Vaihar Road,Tunga Village Chandivali (Andhert East Mumbai-40072

[3]. Organic Tracts (2017),Organic Information Services Pvt ltd,603,55 Corporate Avenue.Saki Vaihar Road,Tunga Village Chandivali (Andhert East Mumbai-40072

[4]. $\quad$ USDA database table for raw cabbage (2014),100 g". US Department of Agriculture, National Nutrient Database for Standard Reference, version $S R-27$.

[5]. Wright, Clifford A. (2001). Mediterranean Vegetables: A Cook's ABC of Vegetables and Their Preparation in Spain, France, Italy, Greece, Turkey, the Middle East, and North Africa with More Than 200 Authentic Recipes for the Home Cook. Harvard Common Press. pp. 77-79. ISBN 978-1-55832-196-0. 
[6]. Decoteau, Dennis R. (2000). Vegetable Crops. Prentice Hall. p. 174. ISBN 978-0-13-956996-8.

[7]. Phillips, Henry (1827). History of Cultivated Vegetables: Comprising their Botanical, Medicinal, Edible, and Chemical Qualities; Natural History. Henry Colburn. p. 99.

[8]. Maria, C. 2007.Study on L-ascorbic acid contents from exotic fruits, Cercatari Agronomice in Moldova, 1(129), 23 -27.

[9]. Lee, H.S. and Contes, G.A. 1999.Vitamin C in frozen, fresh squeezed, unpasteurized, polyethylene-bottled orange juice: A storage study, Food Chemistry, 65, 165-168

[10]. Johnson, J.R., Braddock, R.J., and Chen C.S. 1995.Kinetics of Ascorbic acid loss and nonenzymatic browning in orange juice serum: Experimental rate constants, Journal of Food Science, 60(3), 502-505.Journal Pharm. life Sci., 4(3), 2489.

[11]. Fellers, P.J. 1988. Shelf life and quality of freshly squeezed, unpasteurized, polyethylene-bottled citrus juice, Journal of Food Science, 53(6), 1699-1702.

[12]. Abioye, A.O., Abioye, V.F., Ade-Omowaye, B.I., and Adedeji, A.A. 2013. Kinetic modeling of Ascorbic acid loss in baobab drink at pasteurization and storage temperatures, IOSR Journal of Environ. Sc., Toxicology and Food Tech. (IOSR-JESTFT), vol. 7(2), pp 17-23.

[13]. Burdurlu, H.S., Koca, N., and Keradeniz, F. 2006. Degradation of vitamin C in citrus juice concentrate during storage, Journal of Food Engineering, Vol. 7, Issue 2, pp211-216.

[14]. Beveridge, T. and Weintraub, S. E. 1995. Effect of blanching pre-treatment on colour and texture of Apple slices at various water activities. Food Res. Int. 28:83-86.

[15]. Fox, B. A. and Cameron, A.G. 1982. Food Science a Chemical Approach. Hodder and Stoughton, London.

[16]. Maharaj, V. And Sankat, C. K. 1996. Quality changes in dehydrated dasheen leaves: effect of blanching pre-treatments and drying conditions. Food Res. Inst. 29:563

[17]. Haas, G. J., Prescott, H. E. and Cante, C. J. 1974. On dehydration and respiration of dry and partially dried vegetables. J. Food Sci. 39:681-684

[18]. Shamaila, M., Durance, T. and Girard, B. 1996. Water blanching effects on headspace volatilities and sensory attributes of carrots. J. Food Sci. 61(6): 1191-1195

[19]. Alzamora, S. M., Hough, G. and Chirife, J. 1985. Mathematical prediction of leaching losses of water soluble vitamins during blanching of Peas. J. Food Technology 20: 251-262

[20]. Biekman, E. S. A., Kroese-Hoedeman, H. I. And Schijvens, E.P.H.M. 1996. Loss of solutes during blanching of Mushrooms (Agaricus bisporus) as a result of shrinkage and extraction. J. Food Eng. 28: 139-152.

[21]. Abdelhaq, E. H. And Labuza, T. P. 1987. Air drying Characteristics of Apricots. J. of Food Sci. 52:342-360

[22]. Dutton, H.J., Baily, G. F. And Kohake, E. 1943. Dehydrated Spinach. Ind. Eng. Chem. 35:1173-1177

[23]. Mohamed, S. and Hassein, R. 1994. Effect of low temperature blanching, cysteine-HCL, N-acetyl-L-cysteine, Na metabisulphite and drying temperatures on the firmness and nutrient content of dried Carrots. J. Food Process. Preserv. 18: 343-348.

[24]. Quintero-Ramos, A., Bourne, M. C. and Anzaldua-Morales, A. 1992. Texture and rehydration of dehydrated Carrots as effected by low by low temperature blanching.J.Food Sci.57: 1127

[25]. Derossi, A., De Pulli, T., and Fione, A.G. 2010. Vitamin C kinetic degradation of strawberry juice stored under variable conditions. Journal of Food Science and Technology, 13, 590 - 595.

[26]. Abaha, T., Subramania, P.A.N., Amaha, W., and Rishi, P.2014,Electrochemical determination and comparison of ascorbic acid in freshly prepared and bottled fruit juices: A cyclic voltammetric study, J. Chem. Pharm. Res., 6(5), 880-888.

[27]. Gunjan, K., and Mangla, D.G. 2012. Analysis of Vitamin C in Commercial and Natural substances by Iodometric Titration found in Nimar and Malwa region, J. Sci. Res. Phar., 1(2),8.

[28]. Iwase, H. 2000.Use of nucleic acids in the mobile phase for the determination of ascorbic acid in foods by highperformance liquid chromatography with electrochemicaldetection, J. Chromatogr. A., 881, 327-330.

[29]. Vermeir, S., Hertog, M.L.A.T.M., Schenk, A., Beullens, K.,Nicolai, B.M., and Lammertyn, J. 2008. Evaluation and optimization oh high-throughput enzymatic essays for fast L-ascorbic acid quantification in fruit and vegetables, Anal. Chim. Acta., 618, 94-101.

[30]. Liao, M.L., and Seib, P.A., 1988. Chemistry of L-ascorbic acid related to foods, Food Chemistry, 30: $289-312$.

[31]. Nwakaudu, M. S., Nkwocha, A. C., Madu, I. K., Enwereji, C. B and Ireaja, I. E.2015. Kinetic Modelling of Vitamin C (Ascorbic Acid) Degradation In Tomato and Pawpaw under Market Storage Conditions. IJCR Vol. 7, Issue, 06, pp.16783-16788.

[32]. Saeed,N.,Faezeh,K. and Fatemeh,M.2007.Extraction and quantitative determination of ascorbic acid during different maturity stages of Rosa Canina L..J.Food Composition and Analysis Volume 21, Issue 4, June 2008, Page $300-305$.

[33]. Bozan, B., Sagdullaev, B.T., Kozar, M., Aripov, K.H.N., Baser, K.H.C., 1998. Comparison of ascorbic and citric acid contents in Rosa canina L. Fruits growing in Central Asian region. Chem. Nat. Compd. 34,687-689.

[34]. Barbara, F.R., Thomas, A.R.and Brian, L.(2017 update).Minitab 17.3.1,Pennsylvania State University.

[35]. Bryman, Alan; Cramer, Duncan (2011). Quantitative Data Analysis with IBM SPSS 17, 18 and 19: A Guide for Social Scientists. New York: Routledge. ISBN 978-0-415-579186.

[36]. Silva, E.M., da Silva, J.S., Pena, R.S., and Rogez, H. 2011. A combined approach to optimize the drying process of flavonoid-rich leaves (Inga edulis) using experimental design and mathematical modeling. Food and Bioproducts Processing, 89:39-46.

[37]. Mitra, J., Shrivastava, S.L., and Rao, P.S. 2011. Vacuum dehydration kinetics of onion slices, Food and Bioproducts Processing, $89: 1-9$

[38]. Achanta,S and Okos,M.R.1996.Predicting the quality of dehydrated foods and biopolymers- research needs and oppournities.Drying Technol.14(6): $1329-1368$

[39]. Hansen,L.T.,Rontved,S.D and Huss,H.H.1998.Microbiological quality and shelf life of cold smoked Salmon from three different processing plants. Food Microbial.15(2): $137-150$

[40]. Haring,W.O.,Hills,C.H.,Jones,S.B.,Stafford,A.E. and Tennes,B.R.1978.Ethyl Oleate sprays to reduce cracking of sweet Cheries.HortScience.13(3):279 $i$

[41]. M.N.A., Perera,C.O.,Tian Min,Ong,B.K. and Chung,K.J.2014.Heat.Heat pump drying under Inert atmosphere.Proceedings of the internation Drying Sympasium,2004.Sao Pauazit,August.22- - 25.Vol A.pp-309 -316 